Journal of Agricultural Sciences
(Tarim Bilimleri Dergisi)

\title{
Determination of Some Growth and Development Characteristics Between Birth and Twelve Months Age in Yerli Kara Cattle
}

\author{
Çağrı Melikşah SAKAR ${ }^{a *}$ (D), Uğur ZÜLKADİR ${ }^{b}$

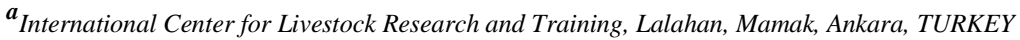

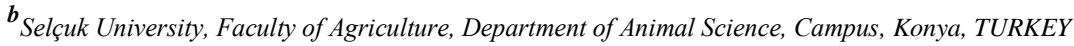 \\ ARTICLE INFO \\ Research Article \\ Corresponding Author: Çağrı Melikşah SAKAR, E-mail: melikksahi@gmail.com \\ Received: 14 April 2020 / Revised: 20 June 2020 / Accepted: 09 October 2020 / Online: 20 January 2022
}

\section{ABSTRACT}

This study was carried out for the purpose of determination of some growth and development characteristics in the period between birth and twelve months of age in Yerli Kara cattle. The animal material of the study was composed of 104 Yerli Kara calves located in Ankara province. In the study, live weight, withers height, rump height, chest girth, body length, chest depth and front wrist girth values at birth were found as $14.85 \mathrm{~kg}, 58.00 \mathrm{~cm}, 60.10 \mathrm{~cm}, 54.41 \mathrm{~cm}, 49.36 \mathrm{~cm}, 24.25 \mathrm{~cm}$ and 7.40 $\mathrm{cm}$ respectively. The same values at the age of three months were found as $49.37 \mathrm{~kg}, 73.95 \mathrm{~cm}, 76.84 \mathrm{~cm}, 83.45 \mathrm{~cm}, 79.14 \mathrm{~cm}, 35.45 \mathrm{~cm}$ and 9.46 $\mathrm{cm}$ respectively. Values at the age of six months in these calves were

Keywords: Average daily gain, Body measurement, Live weight, Yerli Kara cattle detected as $81.22 \mathrm{~kg}, 87.29 \mathrm{~cm}, 90.35 \mathrm{~cm}, 99.36 \mathrm{~cm}, 92.93 \mathrm{~cm}, 42.79 \mathrm{~cm}$ and $10.58 \mathrm{~cm}$ respectively. Values at the age of twelve-month were determined as $97.29 \mathrm{~kg}, 92.15 \mathrm{~cm}, 95.55 \mathrm{~cm}, 106.22 \mathrm{~cm}, 98.07 \mathrm{~cm}, 45.26$ $\mathrm{cm}$ and $10.74 \mathrm{~cm}$ in the same order. Average daily gains values were found $0.360 \mathrm{~kg}$ in the period between birth and 3 months of age, $0.333 \mathrm{~kg}$ from 3 to 6 months, and $0.102 \mathrm{~kg}$ from 6 to 12 months. The results showed that the body measurements of animals in this study are generally lower than the values reported in literature. Therefore, a selection program considering this fact will be useful for the development of native Yerli Kara cattle maintained at the farm operations of Ankara province.

(C) Ankara University, Faculty of Agriculture

\section{Introduction}

Turkey has a great potential in terms of cattle presence and it is among the leading countries in the world with 18 million cattle. $9.23 \%$ of these cattle are indigenous breeds (TUIK 2020). In this context, Yerli Kara cattle which is the best locally adapted breed to the inefficient conditions is the domestic cattle breed with the highest number and largest living area in Central Anatolia of Turkey (Boztepe et al. 2015; Ünal et al. 2019). They are grown extensively in mountainous regions, and primitive maintenance, feeding and barn conditions.

Growth and development characteristics are of great importance in cattle which is the most important source of meat and milk production. In cattle breeding, as a measure of growth and development, various body measurements are taken as basis. The most important of these parameters is birth weight. Birth weight is the easiest and most reliable measure of prenatal growth and an important factor affecting postnatal growth and development (Akbulut et al. 2001; Karabulut et al. 2012). Özhan et al. (2012) have reported that the calves with an average birth weight of $32 \mathrm{~kg}$ growed up faster than the calves with an average of $23 \mathrm{~kg}$ in a herd. Therefore, it is also of great importance in economic terms. Other body measurements such as withers height, rump height, chest girth, body length are also characters that are effective on growth and development (Akbulut et al. 2001; Bilgiç and Alıç 2004; Wu et al. 2004; Karabulut et al. 2012). There are several factors that have effect on the birth weight and body measurements of a calf. The effected environmental factors can be listed as maternal age and weight at birth, maternal ability, nutrition, year and season of calving (Souza et al. 1994; Akbulut et al. 1998; Kaygisiz et al. 1998).

There are limited number of studies showing about live weight and body measurements for Yerli Kara cattle. It is also important to determine the effect of environmental factors on these characteristics to reveal the growth and development performance up to one year in the conditions of the region where the Yerli Kara cattle is widely grown. This study was carried out to determine some growth and development characteristics in the birth and 3,6 and 12 months of age of Yerli Kara calves maintained at different farms. In addition, average daily gains of the animals were determined in the specified periods. 


\section{Material and Methods}

The animal material of this study was consisted of Yerli Kara Cattle grown in private farm operations located in Osmansin village, Çamlidere district of Ankara. This breed has been conserving within the scope of the project of "Conservation of Domestic Genetic Resources and Sustainable Use" conducted by General Directorate of Agriculture Research and Policies (TAGEM). The study was carried out on a total of 104 heads Yerli Kara from 20 different farms. Calves under study was born in January, February, and March of 2018.

In this region, Yerli Kara breeding is mostly carried out as extensive livestock system which is also named as a traditional farming. The animals are kept in the barns during the winter, while they are raised in the pasture in summer. In spring and autumn periods, the animals are kept in the barn of the farms in the village at night, and they are sent to pasture around the village in the daytime. The animals are taken to the uplands of village in early May. In the summer period, the animals are grazed completely in the pasture during the day. They are kept in a corner of the pasture or surrounded barnyards by nights. No additional feed is given to the animals grazed in the pasture. In winter, animals are kept in completely closed village barns under poor care and feeding conditions. In the winter period, animals are fed with only straw and some farms provide very little additional meadow grass and concentrate feed. This situation causes to animals having a skinny and weak appearance after the winter months.

In the study, the data collected from 104 calves at birth and 3 months of age and from 102 and 97 calves at 6 and 12 months of age respectively. The data of birth period were taken within the first 24 hours after calves were born. Weights at 3,6 and 12 months of age were taken in the mornings with an empty stomach. In addition to live weight (LW), withers height (WH), rump height (RH), chest girth (CG), body length (BL), chest depth (CD) and front wrist girth (FWG) were taken (Anonymous, 2020). Body weights and measurements of the animals were determined with a scale sensitive to $200 \mathrm{~g}$, measuring stick and measuring tape.

The analyses of variance by Minitab 16 were used in the evaluation of data (Minitab 2010). The test of Tukey provided by Minitab were realized for multiple comparisons.-Live weights and body measurements including average daily gains of calves were analyzed by using the following statistical model (General Linear Model procedure):

$\mathrm{Y}_{i j k l m}=\mu+\mathrm{a}_{i}+\mathrm{b}_{j}+\mathrm{c}_{\mathrm{k}}+\mathrm{d}_{1}+\mathrm{e}_{i j k l m}$

Where; $Y_{i j k l m}$ : observed data; $\mu$ : Overall mean; $\mathrm{a}_{i}$ : i. effect of calf's gender ( 1 :female, $\left.2: \mathrm{male}\right)$; $\mathrm{b}_{\mathrm{j}}: \mathrm{j}$. effect of maternal age $(2-3,4-6,7+) ; c_{k}$ : k. effect of birth month (1:January, 2:February, 3:March); $\mathrm{d}_{1}$ : 1. effect of farms (1. farm, ... 20. farm); $\mathrm{e}_{i j k l m}$ : random error.

\section{Results and Discussion}

\subsection{Growth and development}

The mean and standard errors (SE) for live weight and body measurements at birth, 3, 6 and 12 months of ages are given in Tables 1, 2, 3 and 4, respectively.

Table 1- The least square mean (LSM) and standard error (SE) values of live weight and body measurements in Yerli Kara cattle at the birth period

\begin{tabular}{|c|c|c|c|c|c|c|c|c|}
\hline Character & $n$ & $L W(\mathrm{~kg})$ & $W H(\mathrm{~cm})$ & $R H(\mathrm{~cm})$ & $C G(\mathrm{~cm})$ & $B L(\mathrm{~cm})$ & $C D(\mathrm{~cm})$ & $F W G(\mathrm{~cm})$ \\
\hline $\begin{array}{l}\text { General } \\
\text { Gende }\end{array}$ & \multicolumn{8}{|c|}{ Gender } \\
\hline Female & 50 & $14.15 \pm 0.446$ & $57.30 \pm 0.560$ & $59.37 \pm 0.581$ & $52.96 \pm 0.640^{\mathrm{b}}$ & $48.67 \pm 0.760$ & $23.84 \pm 0.344$ & $7.01 \pm 0.095^{\mathrm{b}}$ \\
\hline Male & 54 & $15.10 \pm 0.448$ & $58.06 \pm 0.561$ & $60.24 \pm 0.583$ & $54.86 \pm 0.642^{\mathrm{a}}$ & $49.02 \pm 0.763$ & $24.08 \pm 0.345$ & $7.55 \pm 0.095^{\mathrm{a}}$ \\
\hline $\begin{array}{l}\text { P values } \\
\text { Maternal }\end{array}$ & ge & 0.079 & 0.254 & 0.213 & 0.015 & 0.696 & 0.555 & 0.001 \\
\hline $2-3$ & 18 & $13.18 \pm 0.685^{b}$ & $55.72 \pm 0.859^{b}$ & $58.01 \pm 0.892^{b}$ & $51.83 \pm 0.982^{b}$ & $46.70 \pm 1.167^{b}$ & $22.95 \pm 0.528^{\mathrm{b}}$ & $7.04 \pm 0.146^{b}$ \\
\hline $4-6$ & 52 & $15.39 \pm 0.401^{\mathrm{a}}$ & $58.47 \pm 0.502^{\mathrm{a}}$ & $60.59 \pm 0.522^{\mathrm{a}}$ & $55.42 \pm 0.574^{\mathrm{a}}$ & $49.94 \pm 0.682^{\mathrm{a}}$ & $24.73 \pm 0.309^{\mathrm{a}}$ & $7.46 \pm 0.085^{\mathrm{a}}$ \\
\hline $7+$ & 34 & $15.29 \pm 0.535^{\mathrm{a}}$ & $58.85 \pm 0.670^{\mathrm{a}}$ & $60.82 \pm 0.696^{\mathrm{a}}$ & $54.48 \pm 0.766^{\mathrm{a}}$ & $49.90 \pm 0.911^{\mathrm{a}}$ & $24.20 \pm 0.412^{\mathrm{a}}$ & $7.35 \pm 0.114^{\mathrm{a}}$ \\
\hline $\begin{array}{l}\text { P values } \\
\text { Birth Mor }\end{array}$ & \multicolumn{7}{|c|}{ Birth Months } & 0.035 \\
\hline January & 21 & $15.43 \pm 0.682$ & $57.92 \pm 0.855$ & $59.95 \pm$ & $54.96 \pm 0.977$ & $48.42 \pm$ & $24.81 \pm 0.526^{\mathrm{a}}$ & $7.27 \pm 0.145$ \\
\hline February & 46 & $14.78 \pm 0.441$ & $57.40 \pm 0.553$ & $59.54 \pm$ & $53.99 \pm 0.632$ & 48.03 & $24.76 \pm 0.340^{\mathrm{a}}$ & $7.38 \pm 0.094$ \\
\hline March & 37 & $13.66 \pm 0.506$ & $57.72 \pm 0.634$ & $59.92 \pm 0.659$ & $52.78 \pm 0.725$ & $50.09 \pm 0.861$ & $22.31 \pm 0.390^{\mathrm{b}}$ & $7.19 \pm 0.108$ \\
\hline$P$ values & & 0.074 & 0.811 & 0.843 & 0.167 & 0.132 & 0.001 & 0.296 \\
\hline & & & & & & & & \\
\hline$P$ values & 104 & 0.122 & 0.812 & 0.781 & 0.328 & 0.131 & 0.761 & 0.254 \\
\hline
\end{tabular}

The differences between the averages expressed in different letters in the same column are important $(\mathrm{P}<0.05)$ 
Table 2- The least square mean (LSM) and standard error (SE) values of live weight and body measurements in Yerli Kara cattle at 3 months of age

\begin{tabular}{|c|c|c|c|c|c|c|c|c|}
\hline Character & $n$ & $L W(k g)$ & $W H(\mathrm{~cm})$ & $R H(\mathrm{~cm})$ & $C G(\mathrm{~cm})$ & $B L(\mathrm{~cm})$ & $C D(\mathrm{~cm})$ & $F W G(\mathrm{~cm})$ \\
\hline $\begin{array}{r}\text { General } \\
\text { Gende }\end{array}$ & \multicolumn{8}{|c|}{ Gender } \\
\hline Female & 50 & $45.98 \pm 1.386$ & $72.92 \pm 1.013$ & $75.69 \pm 1.027$ & $82.16 \pm 0.942$ & $77.16 \pm 1.001$ & $34.43 \pm 0.537$ & $9.17 \pm 0.097^{\mathrm{b}}$ \\
\hline Male & 54 & $48.83 \pm 1.390$ & $74.02 \pm 1.016$ & $76.94 \pm 1.031$ & $83.50 \pm 0.945$ & $77.98 \pm 1.010$ & $35.49 \pm 0.538$ & $9.67 \pm 0.097^{\mathrm{a}}$ \\
\hline $\begin{array}{l}\text { P values } \\
\text { Maternal }\end{array}$ & \multicolumn{7}{|c|}{ Maternal Age } & 0.001 \\
\hline $2-3$ & 18 & $41.98 \pm 2.128^{b}$ & $70.94 \pm 1.556^{\mathrm{b}}$ & $73.67 \pm 1.577^{b}$ & $79.61 \pm 1.447^{b}$ & $74.98 \pm 1.546$ & $34.01 \pm 0.824$ & $9.16 \pm 0.149^{b}$ \\
\hline $4-6$ & 52 & $49.59 \pm 1.244^{\mathrm{a}}$ & $73.52 \pm 0.909^{\mathrm{a} b}$ & $76.38 \pm 0.922^{\mathrm{a} b}$ & $83.76 \pm 0.846^{\mathrm{ab}}$ & $78.68 \pm 0.903$ & $34.78 \pm 0.482$ & $9.46 \pm 0.087^{\mathrm{ab}}$ \\
\hline $\begin{array}{l}7+ \\
P \text { values }\end{array}$ & 34 & $\begin{array}{c}50.66 \pm 1.660^{\mathrm{a}} \\
0.002\end{array}$ & $\begin{array}{c}75.95 \pm 1.214^{\mathrm{a}} \\
0.024\end{array}$ & $\begin{array}{c}78.90 \pm 1.230^{\mathrm{a}} \\
0.020\end{array}$ & $\begin{array}{c}85.13 \pm 1.128^{\mathrm{a}} \\
0.007\end{array}$ & $\begin{array}{c}79.06 \pm 1.206 \\
0.062\end{array}$ & $\begin{array}{c}36.10 \pm 0.643 \\
0.071\end{array}$ & $\begin{array}{c}9.65 \pm 0.117^{\mathrm{a}} \\
0.025\end{array}$ \\
\hline \multicolumn{9}{|c|}{ Birth Months } \\
\hline January & 21 & $47.57 \pm 2.117$ & $73.61 \pm 1.548$ & $76.10 \pm 1.569$ & $82.13 \pm 1.439$ & $76.31 \pm 1.538$ & $34.56 \pm 0.820$ & $9.38 \pm 0.149$ \\
\hline February & 46 & $47.36 \pm 1.370$ & $73.23 \pm 1.002$ & $76.06 \pm 1.015$ & $82.79 \pm 0.931$ & $77.78 \pm 0.995$ & $34.87 \pm 0.531$ & $9.41 \pm 0.096$ \\
\hline March & 37 & $47.29 \pm 1.571$ & $73.56 \pm 1.148$ & $76.79 \pm 1.164$ & $83.58 \pm 1.068$ & $78.62 \pm 1.141$ & $35.46 \pm 0.608$ & $9.47 \pm 0.110$ \\
\hline$P$ values & & 0.994 & 0.957 & 0.864 & 0.690 & 0.466 & 0.611 & 0.848 \\
\hline $\begin{array}{l}\text { Farms } \\
\mathrm{P} \text { values }\end{array}$ & 104 & 0.002 & 0.168 & 1.161 & 0.008 & 0.019 & 0.007 & 0.028 \\
\hline
\end{tabular}

The differences between the averages expressed in different letters in the same column are important $(\mathrm{P}<0.05)$

Table 3- The least square mean (LSM) and standard error (SE) values of live weight and body measurements in Yerli Kara cattle at 6 months of age

\begin{tabular}{|c|c|c|c|c|c|c|c|c|}
\hline Character & $n$ & $L W(k g)$ & $W H(\mathrm{~cm})$ & $R H(\mathrm{~cm})$ & $C G(\mathrm{~cm})$ & $B L(\mathrm{~cm})$ & $C D(\mathrm{~cm})$ & $F W G(\mathrm{~cm})$ \\
\hline $\begin{array}{l}\text { General } \\
\text { Gende }\end{array}$ & 102 & $78.19 \pm 1.705$ & $86.46 \pm 0.610$ & $89.67 \pm 0.619$ & $98.31 \pm 0.789$ & $91.62 \pm 0.895$ & $42.11 \pm 0.370$ & $10.45 \pm 0.081$ \\
\hline Female & 48 & $75.81 \pm 2.151$ & $85.83 \pm 0.769$ & $89.24 \pm 0.781$ & $98.05 \pm 0.996$ & $91.40 \pm 1.129$ & $42.13 \pm 0.467$ & $10.19 \pm 0.102^{b}$ \\
\hline Male & 54 & $80.58 \pm 2.072$ & $87.09 \pm 0.741$ & $90.10 \pm 0.752$ & $98.58 \pm 0.959$ & $91.85 \pm 1.087$ & $42.10 \pm 0.449$ & $10.70 \pm 0.098^{\mathrm{a}}$ \\
\hline \multicolumn{8}{|c|}{ Maternal Age } & 0.001 \\
\hline $2-3$ & 18 & $70.26 \pm 3.182^{b}$ & $84.10 \pm 1.138^{b}$ & $87.04 \pm 1.155^{b}$ & $94.59 \pm 1.473^{b}$ & $88.47 \pm 1.670^{\mathrm{b}}$ & $40.84 \pm 0.690^{b}$ & $10.13 \pm 0.151^{b}$ \\
\hline $4-6$ & 50 & $81.72 \pm 1.937^{\mathrm{a}}$ & $87.45 \pm 0.693^{\mathrm{a}}$ & $90.67 \pm 0.703^{a}$ & $99.98 \pm 0.897^{\mathrm{a}}$ & $92.61 \pm 1.017^{\mathrm{a}}$ & $43.14 \pm 0.420^{\mathrm{a}}$ & $10.50 \pm 0.092^{\mathrm{ab}}$ \\
\hline $\begin{array}{l}7+ \\
P \text { values }\end{array}$ & 34 & $\begin{array}{c}82.60 \pm 2.491^{\mathrm{a}} \\
0.003\end{array}$ & $\begin{array}{c}87.83 \pm 0.891^{\mathrm{a}} \\
0.015\end{array}$ & $\begin{array}{c}91.29 \pm 0.904^{\mathrm{a}} \\
0.006\end{array}$ & $\begin{array}{c}100.38 \pm 1.153^{\mathrm{a}} \\
0.002\end{array}$ & $\begin{array}{c}93.79 \pm 1.307^{\mathrm{a}} \\
0.026\end{array}$ & $\begin{array}{c}42.37 \pm 0.540^{\mathrm{a}} \\
0.013\end{array}$ & $\begin{array}{c}10.71 \pm 0.118^{\mathrm{a}} \\
0.006\end{array}$ \\
\hline \multicolumn{9}{|c|}{ Birth Months } \\
\hline January & 21 & $79.62 \pm 3.167$ & $87.89 \pm 1.133$ & $91.05 \pm 1.149$ & $100.74 \pm 1.466^{\mathrm{a}}$ & $91.97 \pm 1.662$ & $42.66 \pm 0.687^{\mathrm{a}}$ & $10.71 \pm 0.151^{\mathrm{a}}$ \\
\hline February & 44 & $80.16 \pm 2.080$ & $86.39 \pm 0.744$ & $89.44 \pm 0.755$ & $97.98 \pm 0.963^{\mathrm{ab}}$ & $92.97 \pm 1.091$ & $42.58 \pm 0.451^{\mathrm{a}}$ & $10.52 \pm 0.099^{\mathrm{a} b}$ \\
\hline March & 37 & $74.80 \pm 2.363$ & $85.10 \pm 0.845$ & $88.51 \pm 0.857$ & $96.24 \pm 1.094^{\mathrm{b}}$ & $89.93 \pm 1.240$ & $41.10 \pm 0.512^{b}$ & $10.11 \pm 0.112^{b}$ \\
\hline $\begin{array}{l}\mathrm{P} \text { values } \\
\text { Farms }\end{array}$ & & 0.151 & 0.124 & 0.192 & 0.044 & 0.119 & 0.042 & 0.002 \\
\hline $\mathrm{P}$ values & 102 & 0.001 & 0.016 & 0.021 & 0.001 & 0.003 & 0.024 & 0.001 \\
\hline
\end{tabular}

The differences between the averages expressed in different letters in the same column are important $(\mathrm{P}<0.05)$

Table 4- The least square mean (LSM) and standard error (SE) values of live weight and body measurements in Yerli Kara cattle at 12 months of age

\begin{tabular}{|c|c|c|c|c|c|c|c|c|}
\hline Character & $n$ & $L W(k g)$ & $W H(\mathrm{~cm})$ & $R H(\mathrm{~cm})$ & $C G(\mathrm{~cm})$ & $B L(\mathrm{~cm})$ & $C D(\mathrm{~cm})$ & $F W G(\mathrm{~cm})$ \\
\hline $\begin{array}{l}\text { General } \\
\text { Gende }\end{array}$ & 97 & $96.80 \pm 1.930$ & $91.47 \pm 0.637$ & $94.91 \pm 0.638$ & $105.59 \pm 0.745$ & $98.16 \pm 0.792$ & $45.13 \pm 0.373$ & $10.58 \pm 0.089$ \\
\hline Female & 47 & $91.73 \pm 2.351^{b}$ & $90.56 \pm 0.776$ & $94.13 \pm 0.777$ & $104.22 \pm 0.907^{b}$ & $97.09 \pm 0.965$ & $44.36 \pm 0.454^{b}$ & $10.27 \pm 0.109^{b}$ \\
\hline Male & 50 & $101.86 \pm 2.351^{\mathrm{a}}$ & $92.38 \pm 0.776$ & $95.70 \pm 0.777$ & $106.96 \pm 0.907^{\mathrm{a}}$ & $99.23 \pm 0.965$ & $45.90 \pm 0.455^{\mathrm{a}}$ & $10.88 \pm 0.109^{\mathrm{a}}$ \\
\hline $\begin{array}{l}\text { P values } \\
\text { Maternal }\end{array}$ & ge & 0.001 & 0.044 & 0.081 & 0.010 & 0.056 & 0.004 & 0.001 \\
\hline $2-3$ & 17 & $91.57 \pm 3.535$ & $89.32 \pm 1.167^{b}$ & $92.58 \pm 1.168^{b}$ & $103.31 \pm 1.364$ & $96.15 \pm 1.451$ & $44.06 \pm 0.683$ & $10.40 \pm 0.163$ \\
\hline $4-6$ & 49 & $99.44 \pm 2.088$ & $92.32 \pm 0.690^{\mathrm{a}}$ & $95.87 \pm 0.690^{\mathrm{a}}$ & $106.69 \pm 0.806$ & $99.06 \pm 0.857$ & $45.77 \pm 0.404$ & $10.58 \pm 0.096$ \\
\hline $7+$ & 31 & $99.38 \pm 2.864$ & $92.76 \pm 0.946^{\mathrm{a}}$ & $96.30 \pm 0.946^{\mathrm{a}}$ & $106.76 \pm 1.105$ & $99.27 \pm 1.176$ & $45.55 \pm 0.554$ & $10.75 \pm 0.132$ \\
\hline $\begin{array}{l}\text { P values } \\
\text { Birth Mor }\end{array}$ & & 0.111 & 0.035 & 0.020 & 0.063 & 0.146 & 0.078 & 0.182 \\
\hline January & 19 & $105.12 \pm 3.545^{\mathrm{a}}$ & $92.91 \pm 1.171$ & $96.24 \pm 1.176$ & $108.13 \pm 1.368^{a}$ & $100.99 \pm 1.455^{\mathrm{a}}$ & $46.28 \pm 0.685^{\mathrm{a}}$ & $10.93 \pm 0.164^{\mathrm{a}}$ \\
\hline February & 43 & $96.79 \pm 2.267^{\mathrm{a}}$ & $91.35 \pm 0.749$ & $94.62 \pm 0.749$ & $105.71 \pm 0.875^{\mathrm{ab}}$ & $99.24 \pm 0.931^{\mathrm{a}}$ & $45.17 \pm 0.438^{a}$ & $10.55 \pm 0.105^{\mathrm{ab}}$ \\
\hline March & 35 & $88.49 \pm 2.574^{b}$ & $90.14 \pm 0.850$ & $93.89 \pm 0.851$ & $102.92 \pm 0.994^{b}$ & $94.25 \pm 1.057^{\mathrm{b}}$ & $43.93 \pm 0.498^{b}$ & $10.25 \pm 0.119^{b}$ \\
\hline$P$ values & & 0.001 & 0.132 & 0.228 & 0.005 & 0.001 & 0.014 & 0.003 \\
\hline $\begin{array}{l}\text { Farms } \\
\text { P values }\end{array}$ & 97 & 0.001 & 0.001 & 0.001 & 0.001 & 0.001 & 0.004 & 0.001 \\
\hline
\end{tabular}

The differences between the averages expressed in different letters in the same column are important $(\mathrm{P}<0.05)$ 
Live weights at birth, 3, 6 and 12 months of ages were found to be $14.85 \mathrm{~kg}, 49.37 \mathrm{~kg}, 81.22 \mathrm{~kg}$ and $97.29 \mathrm{~kg}$ respectively. Live weight from birth to 12 months of age for above mentioned traits were lower than the reported ranges (Demirhan 2008; Kılıçel 2014; Ünal et al. 2019) of 16.97- $21.35 \mathrm{~kg}, 63.21$ - $68.18 \mathrm{~kg}, 101.04$ - $110.33 \mathrm{~kg}, 152.16 \mathrm{~kg}-184.57 \mathrm{~kg}$, respectively. In addition, all body size values reported in the birth period were found to be lower than all values reported in the same literatures. In these periods, only body length value was found to be similar to the literature reports. In the study, the effect of gender was determined to be significant $(\mathrm{P}<0.05)$ in only the FWG in all measurement periods (Tables $1,2,3$ and 4 ). In terms of body measurements, in the birth period the effect of gender on WH, CG, CD and BL values were reported (Demirhan 2008; Kıliçel 2014; Ünal et al. 2019) to be not significant, and FWG values as significant $(\mathrm{P}<0.05)$ and these findings were consistent with the values in our study. Demirhan (2008) found that the effect of gender was not significant in WH, CG, BL values in the other three periods (3, 6, 12 months). Kılıçel (2014) found that the effect of gender on WH and CG values at 3 months of age CG value BL at 12 months of age was significant while the same values found to be not significant in other periods.

In the studies conducted with our other local breeds in Turkey, Ünalan and Iş1k (2007) found significant $(\mathrm{P}<0.01)$ effect of gender on live weight and front wrist girth and not significant for withers height, body length, chest girth and middle rump width in the period of birth for the South Anatolian Red calves. Özlütürk et al. (2007) found that the effect of gender on live weights and body measurements in Eastern Anatolian Red calves were significant $(\mathrm{P}<0.01)$ in favor of male calves for birth, 3 and 6 months of age and not significant for 9 and 12 months of age.

In the studies conducted with other breeds, the effect of gender on live weight and body measurements of Holstein calves has been found by Hizli et al. (2017) as significant $(\mathrm{P}<0.01)$ in birth and weaning $(75$ days) but not significant at the age of 6 months. Ayaşan et al. (2016) found a significant $(\mathrm{P}<0.05)$ effect in birth period but not significant for weaning $(75$ days $)$ and 6 months old Holstein calves. Bayril and Yilmaz (2010) have not found a significant effect of gender on birth, weaning (60 days) and 6 months old weight in Holstein calves. Koçak et al. (2008) found a significant $(\mathrm{P}<0.001)$ effect of gender on the birth period weight in the Holstein, Brown-Swiss and Simental calves grown in Lalahan Livestock Research Institute.

Abera et al. (2012) found that birth weight of the calves significantly $(\mathrm{P}<0.05)$ influenced by sex, where male calves were heavier than females at birth. However, female calves were superior $(\mathrm{P}<0.05)$ at weaning and yearling and also had faster growth rate than male calves. Villalba et al. (2000) found a significant $(\mathrm{P}<0.05)$ effect of sex on body weight in birth, 4, 5 and 6 months of age of Brown Swiss and Pirenaica breeds.

When the maternal age values in Tables 1, 2, 3 and 4 are examined, calves born from 4-6 years old cows and 7 years old cows and above were found to be superior to calves born from 2-3 years old cows in all measurement parameters, for the period of birth. In other periods (3, 6 and 12 months) the 7 years old age and above had higher values, and the 2-3 years old age group was found to be at the lowest values, in all measured parameters. The statistical difference between the groups was found to be significant $(\mathrm{P}<0.05)$ in all measurement parameters at birth and at 6 months of age. The effect of maternal age at 3-month was found to be significant $(\mathrm{P}<0.05)$ in $\mathrm{LW}, \mathrm{WH}, \mathrm{RH}$ and $\mathrm{CG}$ values. The 12-month period for this factor was found to be also significant $(\mathrm{P}<0.05)$ in WH and RH values. Demirhan (2008) found BW and WG values in the birth period, all values (LW, WG, $\mathrm{CG}, \mathrm{BL}, \mathrm{WH})$ at 3 and 6 months of age, LW, WG, CG and BL values at 12 months of age in favor of calves born from first calving cows compared with calves of two or more calving cows. K1lıçel (2014) found the LW, WH, CG and BL values in favor of calves born from two or more calving cows compared with calves from first calving cows, in all measurement periods. Ünal et al. (2019) found the BW, WH, RH, CG, BL, CD and FWG values in the period of birth in favor of calves born from five years old and above calving cows compared with calves from four years and under calving cows.

In the studies conducted with our other local breeds for the effect of the maternal age, Ünalan \& Iş1k (2007) found not significant values for LW, WH, BL, CG, and FWG in the period of birth in the calves of South Anatolian Red calves. Özlütürk et al. (2007) found significant $(\mathrm{P}<0.01)$ values for live weights in Eastern Anatolian Red calves in favor of male calves in birth, 6 and 12 months of age and not significant at 3 and 9 months of age.

As for the studies conducted with other breeds, the effect of maternal age on live weight; Hizli et al. (2017) found a significant $(\mathrm{P}<0.01)$ effect in birth, weaning (75 days) and 6 months weight for Holstein calves. Ayaşan et al. (2016) found significant $(\mathrm{P}<0.05)$ effect of maternal age on birth, weaning (75 days) and 6 months old weight in Holstein calves. Bayril \& Y1lmaz (2010) did not find any significant effect of maternal age on birth, weaning (60 days) and 6 months old weight of Holstein calves. Koçak et al. (2008) found significant $(\mathrm{P}<0.001)$ effect of maternal age on the birth weight in the Holstein, Brown-Swiss and Simental calves grown in Lalahan Livestock Research Institute. Villalba et al. (2000) found a significant $(\mathrm{P}<0.05)$ effect of maternal age on 5 and 6 months of age weight but not significant in birth and 4 months of age in Brown Swiss and Pirenaica breeds calves.

In the current study, live weight and body size values generally were found to be lower than literature reports in all measurement periods. In the study area births are taken place in January, February and March. Therefore, the animals that will give birth in winter are housed in completely closed and stuffy barns, under insufficient care and feeding conditions. These situations prevent of calf development in the period of before and after birth. In addition, calves return from the pasture to the village after 7-8 months of age and housed the winter months on the farmings in the village. The animals cannot get enough nutrients here, which cause slower rate in the growth of the animals. This can explain the reason for the measurement values of 
the 12-months calves, which are not significantly higher than the values of the six-months calves. The fact that other study results are better than the findings of the current study may be due to the better care and feeding of the animals in the institute environment.

Although the effect of gender in the growth periods of Yerli Kara cattle except for a few characteristics was statistically not significant, it was determined that the development of male calves was superior in all measurement periods (Tables 1 , 2, 3 and 4).

This is the evidence of sex hormones affect growth positively and which is in coincide with the literature (Demirhan 2008; K1liçel 2014; Ünal et al 2019). When according to the maternal age is examined, calves born from cattle of 4-6 years old age and 7 years old age and above were found to be superior to calves born from cattle of 2-3 years old age in all measurement parameters (Tables 1, 2, 3 and 4). This may be due to the fact that 2-3-year-old cows are not fully able to complete their development, and because they are the first calves in general, their maternity abilities do not fully develop and do not feed the calf adequately. In addition, since the calves are always with their mothers in Yerli Kara cattle, the effect of the maternal age continued in the following periods ( 6 and 12 months).

\subsection{Average daily gains $(A D G)$}

ADG values from birth to the $12^{\text {th }}$ month in Yerli Kara calves presented in Table 5. In the study, ADG values were found to be $0.360 \mathrm{~kg}$ in the period between birth to 3 months, $0.333 \mathrm{~kg}$ in the period between 3 and 6 months and $0.102 \mathrm{~kg}$ in the period between 6 and 12 months. It can be said that the ADG of the animals are at the desired levels since values are above the targeted $300 \mathrm{~g}$ increase in both the periods between birth and 3 months and 3 and 6 months. The calf's genetic capacity, environmental factors and especially the milk provided by the mother to the calf determine the sucking period growth of the calves, and in this period, environmental factors have more effect than genetic factors (Alpan \& Aksoy 2012).

Table 5- The least square mean (LSM) and standard error (SE) of average daily gains in Yerli Kara cattle between birth and 12 months of age

\begin{tabular}{|c|c|c|c|c|c|c|}
\hline Period & $n$ & Birth - 3 Months & $n$ & $3-6$ Months & $n$ & $6-12$ Months \\
\hline General & 104 & $0.360 \pm 0.010$ & 102 & $0.333 \pm 0.012$ & 97 & $0.102 \pm 0.006$ \\
\hline \multicolumn{7}{|c|}{ Gender } \\
\hline Female & 50 & $0.350 \pm 0.013$ & 48 & $0.320 \pm 0.016$ & 47 & $0.087 \pm 0.006^{b}$ \\
\hline Male & 54 & $0.371 \pm 0.013$ & 54 & $0.346 \pm 0.015$ & 50 & $0.116 \pm 0.006^{\mathrm{a}}$ \\
\hline $\mathrm{P}$ values & & 0.184 & & 0.146 & & 0.001 \\
\hline \multicolumn{7}{|c|}{ Maternal Age } \\
\hline $2-3$ & 18 & $0.316 \pm 0.020^{\mathrm{b}}$ & 18 & $0.305 \pm 0.023$ & 17 & $0.125 \pm 0.011^{\mathrm{a}}$ \\
\hline $4-6$ & 52 & $0.376 \pm 0.012^{\mathrm{ab}}$ & 50 & $0.348 \pm 0.014$ & 49 & $0.095 \pm 0.007^{\mathrm{ab}}$ \\
\hline $7+$ & 34 & $0.389 \pm 0.016^{\mathrm{a}}$ & 34 & $0.346 \pm 0.018$ & 31 & $0.086 \pm 0.009^{b}$ \\
\hline$P$ values & & 0.010 & & 0.228 & & 0.016 \\
\hline \multicolumn{7}{|c|}{ Birth Months } \\
\hline January & 21 & $0.353 \pm 0.020$ & 21 & $0.347 \pm 0.023^{\mathrm{a}}$ & 19 & $0.142 \pm 0.011^{\mathrm{a}}$ \\
\hline February & 46 & $0.358 \pm 0.013$ & 44 & $0.355 \pm 0.015^{\mathrm{a}}$ & 43 & $0.096 \pm 0.007^{\mathrm{b}}$ \\
\hline March & 37 & $0.370 \pm 0.015$ & 37 & $0.297 \pm 0.017^{b}$ & 35 & $0.068 \pm 0.008^{\mathrm{c}}$ \\
\hline $\mathrm{P}$ values & & 0.747 & & 0.017 & & 0.001 \\
\hline \multicolumn{7}{|c|}{ Farms } \\
\hline $\mathrm{P}$ values & & 0.001 & & 0.011 & & 0.001 \\
\hline
\end{tabular}

The differences between the averages expressed in different letters in the same column are important $(\mathrm{P}<0.05)$

The values found in the current study comply with the information stated by Alpan \& Aksoy (2012) who stated the ability of animals to utilize nutrients at the highest level therefore the highest level for the ADG. Also, it complies with the information that Estermann et al. (2003) reported that calves born at the end of the winter season are relatively higher ADG than other times. In addition, in accordance with the findings in the study, Casasus et al. (2002) reported that calves kept in pasture together with their mothers reached a lower live weight for those born in autumn compared to those born in spring in terms of 6-month live weight.

However, in the study, ADG slowed down significantly in period between 6-12 months. This may be due to the fact that this period coincides with the autumn and winter months and the animals is housed under insufficient care and feeding conditions of winter. Roth et al. (2008) reported that ADG slowed down in cases where weaning performed quickly in calves with weak body resistance and due to of the calves not being fed enough during this period. This information is accordance with the findings obtained in the current study. 


\section{Conclusions}

The results determined in the research show that the live weights and body sizes of the calves are not at the desired level in the Yerli Kara cattle breed. In general, live weight and some body measurements were lower than the literature reports in all measurement periods. It was concluded that this might have been due to the maintenance and feeding conditions of farmer where the study was conducted. In addition, the animal material of this research was selected from different farms and also different breeder conditions. LW and body measurements of animals were taken in pasture conditions. Like these, it is thought that some uncontrollable environmental factors have negative effects. The fact that there is a limited number of resources related to the growth and development of Yerli Kara cattle is another negative factor in terms of comparison of the findings obtained. To prevent this, farmers need to make improvements in environmental factors. It is necessary to provide feed supplements at least to meet the nutrients needed by animals and to improve barn conditions. In addition, the application of adding outbred bulls to prevent inbreeding without disturbing the purity of the populations may prevent the problems that will occur genetically.

\section{Acknowledgments}

This study was prepared from the doctoral dissertation of Çağrı Melikşah SAKAR, who is the first name in the article. We would like to thank "Selçuk University, Scientific Research Projects Coordination Unit" for supporting this study with the project numbered 18201039 and TAGEM who gave the necessary permission to provide the material used.

\begin{tabular}{|ll|}
\hline \multicolumn{2}{|l|}{ Abbreviations and Symbols } \\
\hline$T A G E M$ & General Directorate of Agriculture Research and Policies \\
$L W$ & live weight \\
$W H$ & withers height \\
$R H$ & rump height \\
$B L$ & body length \\
$C D$ & chest depth \\
$F W G$ & front wrist girth \\
$S E$ & standard error \\
$n$ & number of materials \\
$P$ & significance value \\
$A D G$ & average daily gains \\
\hline
\end{tabular}

\section{References}

Abera H, Abegaz S \& Mekasha Y (2012). Influence of non-genetic factors on growth traits of Horro (Zebu) and their crosses with Holstein Friesian and Jersey cattle. International Journal of Livestock Production 3(7): 72-77. https://doi: 10.5897/IJLP11.015

Akbulut Ö, Tüzemen N, Yanar M \& Aydın R (1998). The relationship of early body weight and body measurements with first lactation milk yield characteristics in brown cattle. Atatürk University Journal of Agricultural Faculty 9(2): 250-258

Akbulut Ö, Bayram B \& Yanar N (2001). Estimates of phenotypic and genetic parameters on birth weight of Brown Swiss and Holstein Friesian calves raised in semi entansif conditions. Journal of Lalahan Livestock Research Institute 41(2): 11-20

Alpan O \& Aksoy A R (2012). Cattle breeding and fattening. 6th edition, Milsan Printing Press, Ankara, pp. 29-242

Anonymous (2020). Measurements taken from cattle. Retrieved in June, 20, 2020 from http://www.muratgorgulu.com.tr/altekran.asp?id=11.

Ayaşan T, Hızlı H, Asarkaya A \& Coşkun M A (2016). Growth performance and survival rate traits in Holstein Calves. Turkish Journal of Agricultural and Natural Sciences 3(3): 223-228

Bayrı T \& Yılmaz O (2010). Growth performance and viability of Holstein calves reared in Kazova Vasfi Diren Farm. Journal of Yüzüncü Yll University Faculty of Veterinary Medicine 21(3): 169-173

Bilgiç N \& Alıç D (2004). Genetic and phenotypic parameter estimates of birth weight in Holstein Friesian calves. Journal of Agricultural Science 10(1): 72-75

Boztepe S, Aytekin İ \& Zülkadir U (2015). Dairy Cattle. Selçuk University Printing Press, 1st edition, Konya, pp. 29

Casasus I, Sanz A, Villalba D, Ferrer R \& Revilla R (2002). Factors affecting animal performance during the grazing season in a mountain cattle production system. Journal of Animal Science 80(6): 1638-1651. https://doi.org/10.2527/2002.8061638x

Demirhan I (2008). Effects of certain factors and inbreeding on different body measurement treats of Yerli Kara cattle, MSc Thesis, Afyon Kocatepe University, Turkey

Estermann B L, Wettstein H R, Sutter F, Erdin D \& Kreuzer M (2003). Effect of calving period on herbage intake and nutrient turnover of Simmental and Angus suckler cows with Angus sired calves grazing subalpine and alpine pastures. Livestock Production Science 79(2-3): 169-182. https://doi.org/10.1016/S0301-6226(02)00152-5

Hızlı H, Ayaşan T, Asarkaya A, Coşkun M A \& Yazgan E (2017). Growth performance and survival rate traits in Holstein Calves raised in east mediterrenean agricultural research institute farm. I $\check{g} d i r$ University Journal of the Institute of Science and Technology 7(1): 383-389

Karabulut O, Mundan D \& Sehar Ö (2012). Variance components and breeding values of birth weight in Holstein calves. Harran University Journal of the Faculty of Veterinary Medicine 1(1): 28-34

Kaygisız A (1998). Estimates of Genetic and phenotypic parameters for birth weight in Brown and Simmental calves raised at Altındere state farm. The Turkish Journal of Veterinary and Animal Sciences 22(6): 527-535

Kilıçel R (2014). Examination of different breeding types in Anatolian Black and Brown Swiss cattles reared in Şile region, PhD Thesis, Selçuk University, Turkey

Koçak S, Tekerli M, Özbeyaz C \& Demirhan İ (2008). Some production traits of Holstein, Brown-Swiss and Simmental Cattle reared in Lalahan Livestock Research Institute. Journal of Lalahan Livestock Research Institute 48(2): 51-57 
Minitab I (2010). Minitab 16 statistical software: Minitab Inc. State College, Pennsylvania

Özhan M, Tüzemen N \& Yanar M (2012). Cattle raising. 6th edition, Faculty of Agriculture Atatürk University Printing Press, Paplication no: 134, Erzurum, pp. 124

Özlütürk A, Güler O, Yanar M, Akbulut Ö, Tüzemen N, Kopuzlu S, Küçüközdemir A \& Yüksel S (2007). Some environmental factors affecting on growth characteristics in Eastern Anatolian Red Cattle. Journal of Tekirdag Agricultural Faculty 4(1):17-26

Roth B A, Hillmann E, Stauffacher M \& Keil N M (2008). Improved weaning reduces cross-sucking and may improve weight gain in dairy calves. Applied Animal Behaviour Science 111(3-4): 251-261. https://doi.org/10.1016/j.applanim.2007.06.007

Souza J C de, Brule A O, Ferraz P B, Oliveira J de A L, Alencar M, Bahiense Ferraz P Jr, Anchieta Leite Oliveira J de \& Mello de Alencar M (1994). Repeatability of body weight and gain from birth to weaning in Nelore Cattle. The Sociedade Brasileira de Zootecnia 23(1): 133139

Ünal İ, Tuncer H İ, Sakar Ç M \& Ünay E (2019). The effect of maternal age on some body measurements in Anatolian Black Calves. Black Sea Journal of Agriculture 2(1): 47-50

Ünalan A \& Işı A (2007). A Study on determination of environmental effects and phenotypic correlations among some body measurements of South Anatolian Red (Kilis) calves. Journal of the Faculty of Agriculture Çukurova University 22(2): 1-6

TUIK (2020). According to years the presence of cattle in Turkey. Retrieved in April, 12, 2020 from http://www.tuik.gov.tr/UstMenu.do?metod=temelist

Villalba D, Casasús I, Sanz A, Estany J \& Revilla R (2000). Preweaning growth curves in Brown Swiss and Pirenaica calves with emphasis on individual variability. Journal of Animal Science 78(5): 1132-11

Wu G, Bazer F W, Cudd T A, Meininger C J \& Spencer T E (2004). Maternal nutrition and fetal development. The Journal of Nutrition 134(9): 2169-2172. https://doi.org/10.1093/jn/134.9.2169

C 2022 by the author(s). Published by Ankara University, Faculty of Agriculture, Ankara, Turkey. This is an Open Access article distributed under the terms and conditions of the Creative Commons Attribution (CC BY) license (http://creativecommons.org/licenses/by/4.0/), which permits unrestricted use, distribution, and reproduction in any medium, provided the original work is properly cited. 